\title{
Paleoenvironmental Distribution Patterns of Sequence Stratigraphy in the Paleocene-Eocene Deposits of Sekonj Trough Event (Central Iran)
}

\author{
Masoud Ghafari', Massih Afghah ${ }^{*}$, Vahid Ahmadi ${ }^{2}$ \\ ${ }^{1}$ Department of Geology, Fars Scince and Research Branch, Islamic Azad University, Fars, Iran \\ ${ }^{2}$ Department of Geology, Shiraz Branch, Islamic Azad University, Shiraz, Iran \\ Email: *massihafg2002@yahoo.com, masoudghafari48@yahoo.com,v_ahmadi_geo@yahoo.com
}

How to cite this paper: Ghafari, M., Afghah, M. and Ahmadi, V. (2017) Paleoenvironmental Distribution Patterns of Sequence Stratigraphy in the Paleocene-Eocene Deposits of Sekonj Trough Event (Central Iran). Open Journal of Geology, 7, 647-665. https://doi.org/10.4236/ojg.2017.75044

Received: March 27, 2017

Accepted: May 21, 2017

Published: May 24, 2017

Copyright ( 92017 by authors and Scientific Research Publishing Inc. This work is licensed under the Creative Commons Attribution International License (CC BY 4.0).

http://creativecommons.org/licenses/by/4.0/

\begin{abstract}
The Paleocene-Eocene successions were studied in Sekonj and Abaregh sections and located in South of Kerman in order to determine the microfacies, depositional environment and sequence stratigraphy. The deposits in the studied area are mainly composed of limestone, sandstone, conglomerate and shale. The obtained data from the field and laboratory observations led to identification of 11 microfacies which represent the coastal, tidal flat, lagoon, barrier and proximal open marine which were deposited in a carbonate-siliciclastic ramp environment. The sedimentology evidences, vertical analysis of microfacies, facies and relative sea level changes represent that the Paleocene-Eocene succession deposits have two 3rd depositional sequences in the studied area. The sequence 2 cannot be recognized completely due to the lack of outcrop. Sequence stratigraphic studies show an upward shallowing trend corresponding to the global sea level changes from the base to the upward of the succession.
\end{abstract}

\section{Keywords}

Paleocene-Eocene, Facies, Depositional Environment, Sequence Stratigraphy, Sekonj Trough

\section{Introduction}

The Paleogene period begins in the most parts of Central Iran and the southern slopes of Alborz with the presence of post-orogenic clastic sediments and with the apparent angular unconformity, but a sedimentary trough was formed at the time of Laramide event and between Sekonj area and Shishtu mountain which predominantly is consists of fine-grained clastic sediments and shows the continuous marine conditions and the continuous, gradual transition of the Creta- 
ceous sediments to Paleogene deposits in the region with its considerable thickness [1]. Laramide event formed the Kerman conglomerate during the late Mesozoic era in most areas of Kerman which represents the marine regression conditions [2]. Laramide orogeny event (late Cretaceous-Paleogene) has an important role in geology of Iran and in the studied area. The initiation, termination and effects of the Laramide orogeny event is not similar in anywhere of Iran and even in an identified structural sedimentary basin [3], but its effects are visible as folding, metamorphic upland and flysch basins on individual structural zones of Iran. Although few studies have been done in the recent years on the stratigraphy of Paleocene-Eocene carbonate sediments in Kerman areas by [4]-[10], but the Sekonj sedimentary trough is not considered. In this study, facies, depositional environment and sequence stratigraphy of the Sekonj and Abaregh sections in Sekonj sedimentary trough will be analyzed.

\section{Materials and Method}

The studied area is located in Central Iran structural zone which its event is associated with the history of this micro-continent. Central Iran micro-continent is considered as a part of central Iran. The sekonj section with a thickness of 414 meter is located at $30^{\circ} 01^{\prime} 48^{\prime \prime} \mathrm{N}$ and $57^{\circ} 29^{\prime} 22^{\prime \prime} \mathrm{E}$, in the north east of sekonj village, in the south ridge of Polvar mountain and in the east flank of anticline, about 25 $\mathrm{km}$ of Mahan city and $50 \mathrm{~km}$ south East of Kerman city (Figure 1) [11]. The Paleocene-Eocene succession in this section is mainly characterized by laminated to thick-bedded, fine to medium-grained, red to brown sandstones bearing olistolith and sandy limestone with interbedded thin layers of shale and alternating with limestones and sandstones. Abaregh section with a thickness of 325 meter is located at $29^{\circ} 20^{\prime} 51^{\prime \prime} \mathrm{N}$ and $57^{\circ} 56^{\prime} 34^{\prime \prime} \mathrm{E}$, about $54 \mathrm{~km}$ of Bam city and in the north west of Abaregh village. The lithostratigraphic units of this section are including: 1) the succession of thick-bedded limestones with sandy limestones, 2) limestone and sandy limestone with interbedded shale, sandstone and conglomerate, 3) sandstone, shale and with interbedded limestone. The Sekonj and

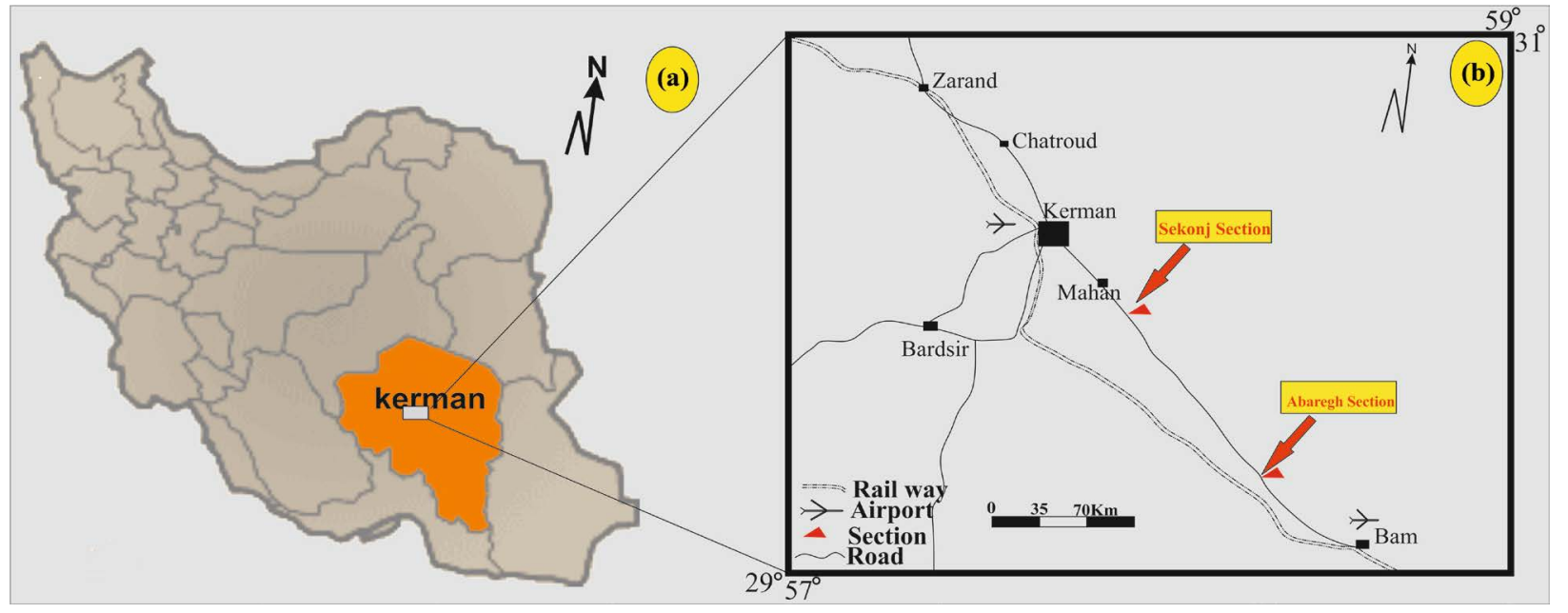

Figure 1. (a) A view of Kerman province position in Iran. (b) Geographical position and access roads of the studied section. 
Abaregh sections are located in the southeast part of Kerman and 1: 100,000 geological maps (Figure 1) [12] [13] and [14]. The general structure of these sections is a flank of the antiform which the oldest rock unit belongs to the pectin-limestone, shale and marl with the veins of gypsum and is cretaceous in age. The youngest rock unit belongs to the Quaternary sediments in the studied area. The biostratigraphy studies show Thanetian-Ypersian age for the studied successions. In terms of tectonically, the studied area is located in the east of Gowk fault (the old name of Golbaf) and is affected by the performance of the fault. Generally, the general structure of Gowk fault system is as a thrust with a ramp geometry and dextral movement (Figure 2) [15] and [16]. Generally, the function of these structures led to many changes in sedimentary facies at short distances, depositional gaps, discontinuities and sudden resection of geological structures in Sekonj sedimentary trough (Figure 2).

In the field studies, based on the observed changes in genus, color, bedding and grain size, 250 samples were taken from the Sekonj and Abaregh successions and thin sections were prepared from them. Abundance of skeletal and nonskeletal allochems were measured based on the compared charts of [17]. The silisiclastic rocks are named by the classification of [18] and the carbonates rocks are basis on the nomenclature of [19]. The results of field observations and laboratory studies led to reconstruction of the sedimentary paleoenvironment and sedimentary model in the studied sections. Analysis of the sequence stratigraphy in the studied sections is based on the sequence stratigraphy principles of [20] [21] and [22].

\section{Sedimentary Facies}

Field observations, analysis of lithology and microscopic studies led to the

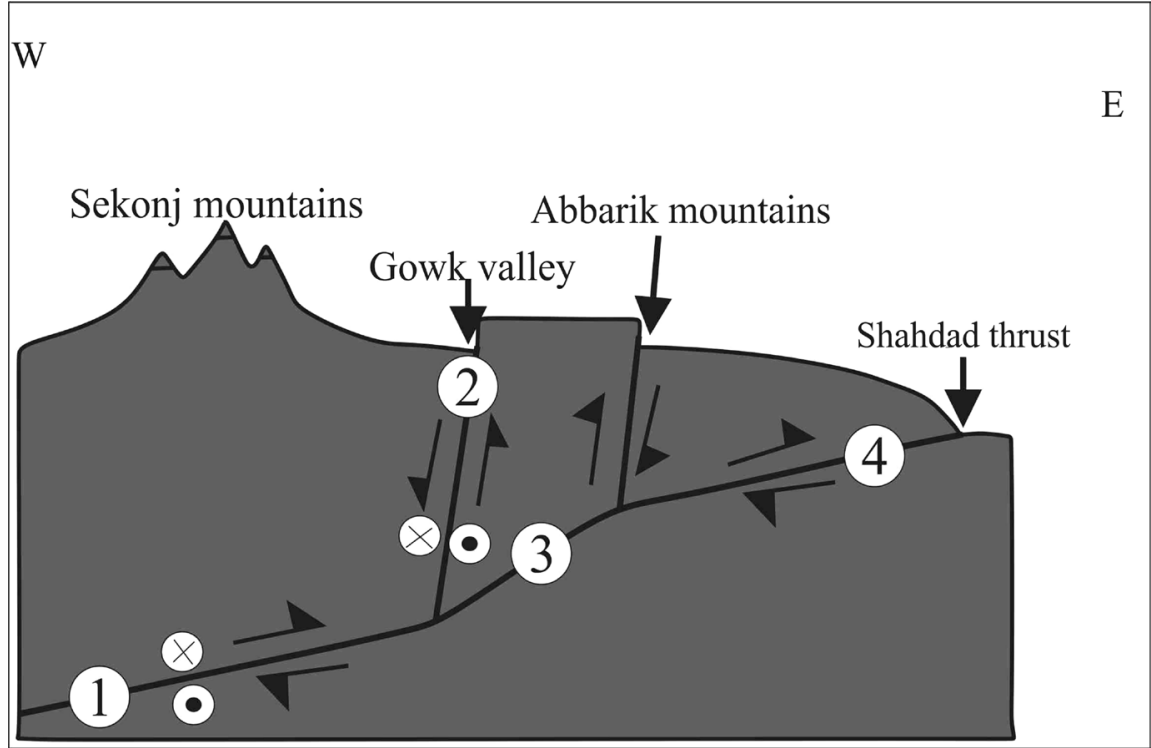

Figure 2. The structure of Gowk fault. The gentle slope parts $(1,4)$ which are separated with a steep slope stair (3), show the net thrust parts and led to uplift Abbarik mountains and the occurrence of normal oblique fault (2) in the Gowk valley. 
identification of 5 facies belts in the form of 11 microfacies and facies (Figure 3 and Figure 4). Thus, the facies and microfcaies which were introduced based on Flugel model (Flugel, 2010) located in the coastal (Mf1, Mf2, Mf3, Mf4), tidal flat (Mf5, Mf7), lagoon (Mf8, Mf9), barrier (Mf10, Mf11) and open marine (Mf13) facies belts.

\subsection{Coastal Facies Belt}

Coastal facies belt are located in the middle to upper part of the Sekonj section and in the lower to the upper part of the Abaregh section and are composed of thin to thick layers. The most observed coastal facies belongs to Mf2.

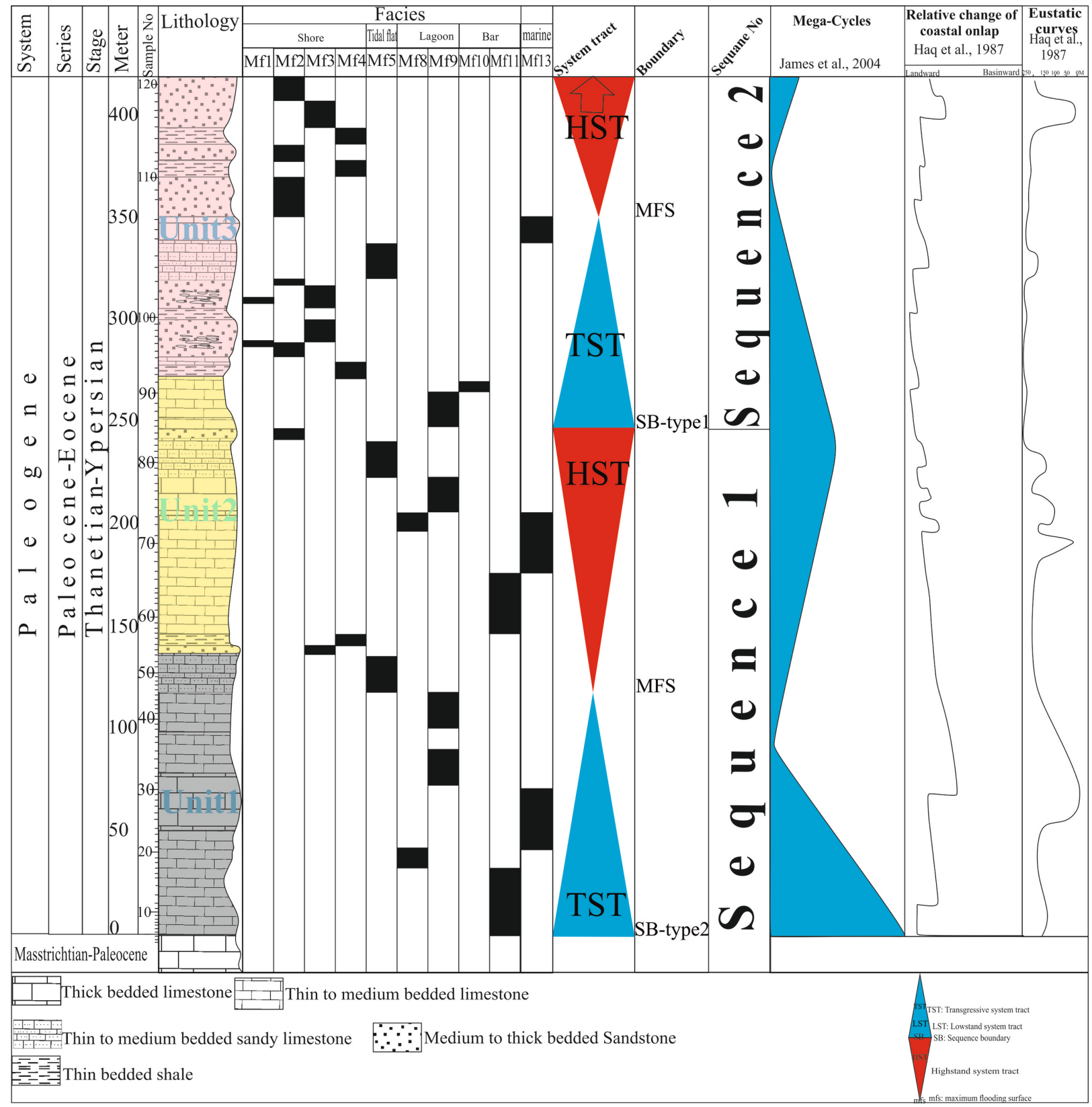

Figure 3. Lithostratigraphy column, facies, sequence stratigraphy and the comparison of global sea level changes in the Sekonj section. 


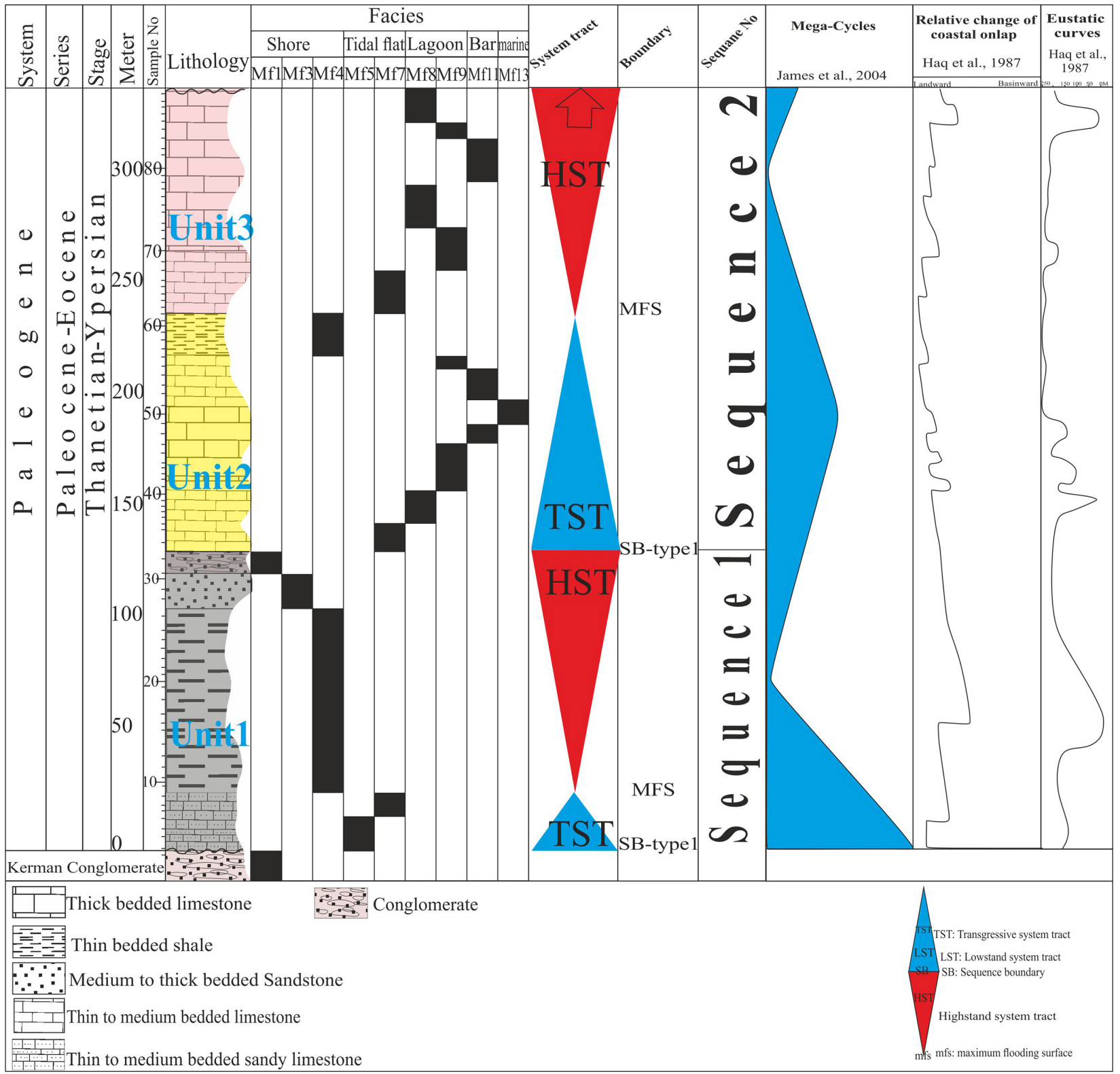

Figure 4. Lithostratigraphy column, facies, sequence stratigraphy and the comparison of global sea level changes in the Abaregh section.

\subsection{Conglomerate (Mf1)}

The sediments of this facies is visible as lens-shaped between the sandstone successions and has a limited lateral extension in the Sekonj section, while it can be seen as identified successions in the lower part of the Abaregh section. The size of the main components are variable between 5 to $100 \mathrm{~mm}$ in this facies which the pebbles and cables are located in the fine to coarse-grained matrix according to the classification of Tucker [23]. The pebbles and cables have contact with together in this lithofacies and show the grain-supported fabric with low matrix according to the classification of Pettijohn. In the field studies, the facies is light to dark gray and can be seen with secondary calcite veins, carbonate, metamorphic and volcaniclastic fragments with poor sorting and moderate to good 
roundness and probably polymodal (probably olistolith) (Figure 5). The conglomerate is polymictic and has a significant percentage of olistolith grain (granule size, granular and massive bedding). The thickness of fragments in the conglomerate succession are reduced laterally and formed in a channel environment. The conglomerate facies probably have been deposited by the processes of river floods and the slow flow of the river. The poor sorting is attributed to the rapid sedimentation and the high accumulation of grains can be the result of interaction between the grains during the flood flows [24].

\section{3. (Quartzarenite) (Mf2)}

This petrofacies is just in the Sekonj section and has been appeared in the various parts of the facies column. The facies probably have been existed in the Abaregh

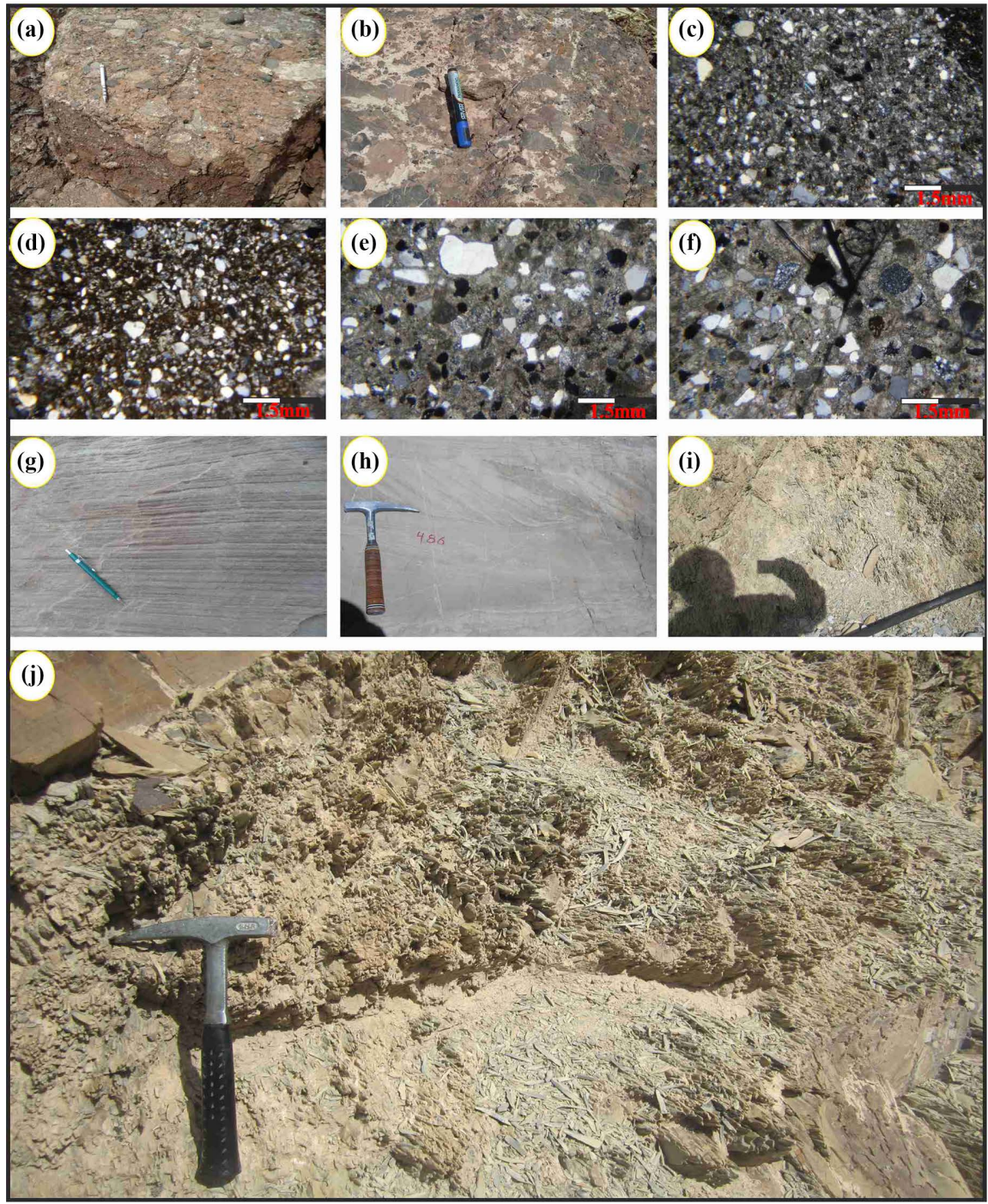

Figure 5. (a), (b) Conglomerate facies. The grain size of this facies is pebble to silt. (c), (d) Quartz arenite petrofacies. The quartz grains are aboundant (XPL). (e), (f) Sublitharenite petrofacies. The quartz and feldspar grains are visible in this petrofacies (XPL). (g) The laminations in the sandstone successions. (h) Cross-lamination in the sandstone succession. (i), (j) A view of shale succession in the studied sections. 
section which has been converted to other sandstone facies during the time. The microfacies is thin to thick-bedded and light brown to white color in the field. The grains of this microfacies are fine to medium-grained, subrounded with good sorting and textural maturity is moderate to good. Alternation of thin layers of shale and sandstone were observed in this microfacies. Its textural maturity is good and monocrystalline quartz grains with parallel extinction and slightly undulatory extinction are with small amount of calcite cement (Figure 5). The contact between quartz grains are straight, sutured and concavo-convex contacts which are caused by pressure solution. The frequency of quartz grains are more than $95 \%$ and are monocrystalline with parallel extinction. Based on the cross and parallel laminations, the sandstones were deposited in a high energy environment which represented a foreshore environment. The absence of fairly good roundness and sorting with olistolith grains indicate rapid tectonic activities which prevent the formation of quartz grains with good sorting. The large amounts of monocrystalline quartz with parallel extinction than other types of grains show the inter cratonic origin [25] and the low frequency of feldspars along with rock fragments can be assumed a source area with strong chemical weathering and long transportation [26]. The presence of cross-bedding, trace fossils and its relationship with other facies represent the deposition of this facies in shallow water environment with different energy [27].

\section{4. (Sublitharenite) (Mf3)}

This petrofacies was observed in the upper part of the succession in the Sekonj section, but has been limited in the lower part of the Abaregh section. Its mineralogical maturity is sub-mature to mature due to the high percentage of quartz and very small amount of chert debris and also the high proportion of dolomite, muscovite and feldspar than to the total sedimentary rock fragments and feldspar. The mineralogical maturity of the microfacies is sub-mature due to the high percentages of quartz and chert than to the total sedimentary rock fragments and feldspar. In the field observations, the facies is brown to light brown-colored in surface sample, thin to medium bedded and bearing cross bedding with alternating shale facies. The frequency of quartz particles are $70 \%$ to $80 \%$, fine to medium-grained and sub-rounded (Figure 5). The grains of the microfacies are fine to medium-grained. In terms of petrological characteristics, is similar to the previous petrofacies which the main difference is the amount of rock fragments. The amounts of rock fragments can be changed between $5 \%-15 \%$. The quartz particles are often monocrystalline but some quartz are polycrystalline. The textural maturity of this petrofacies is often immature and sometimes sub-mature. The types of sandstone petrofacies and their textural characteristics such as the types of main grains and the proportion between them, the mature textural maturity and good sorting represent a shore face environment.

\subsection{Shale (Mf4)}

The facies has most extensive in the lower part of the facies column in the Sekonj 
section which has been exposed with alternating and interbedded with other lithological units. In the field observations, the facies is black to gray-colored, foliated, very soft and non-fossil which can be seen in carbonates with approximately high thickness in compared of alternating with sandstones (Figure 6). The presence of fine-grained quartz grains represent that the facies gradually changed to siltstone in some units. Alternating layers of sandstone and shale indicate deposition of shale facies in a mud plain, in shallow coastal environments. The shales with low thickness were mainly deposited in a mud plain near the sea and with alternating sandstone facies of shallow coastal environment and carbonate rocks. The high lateral extension of shale facies between the semi-restricted deposits indicates reduction of environment mechanical energy in mud plain.

\section{Tidal Flat Facies Belt}

This facies belt is composed of 2 microfacies which can be seen with thin to thick-bedded layers throughout the clastic-carbonate succession. The most observed coastal facies belongs to Mf5.

\subsection{Sandy Mudstone (Mf5)}

The microfacies observed in both sections, in the lower part of the Abaregh section and in the different parts of the Sekonj section in the studied succession. The size of the sands is very fine to coarse-grained. The average frequency of components in the microfacies are including quartz particles about $10 \%-20 \%$, matrix $45 \%$, rock fragments $8 \%$ and calcareous cement $10 \%$.

More quartz grains are rounded and slightly angular, in the form of single crystal and polycrystalline with parallel extinction, although a few of them has undulatory extinction (Figure 6). It seems that the quartz particles are formed

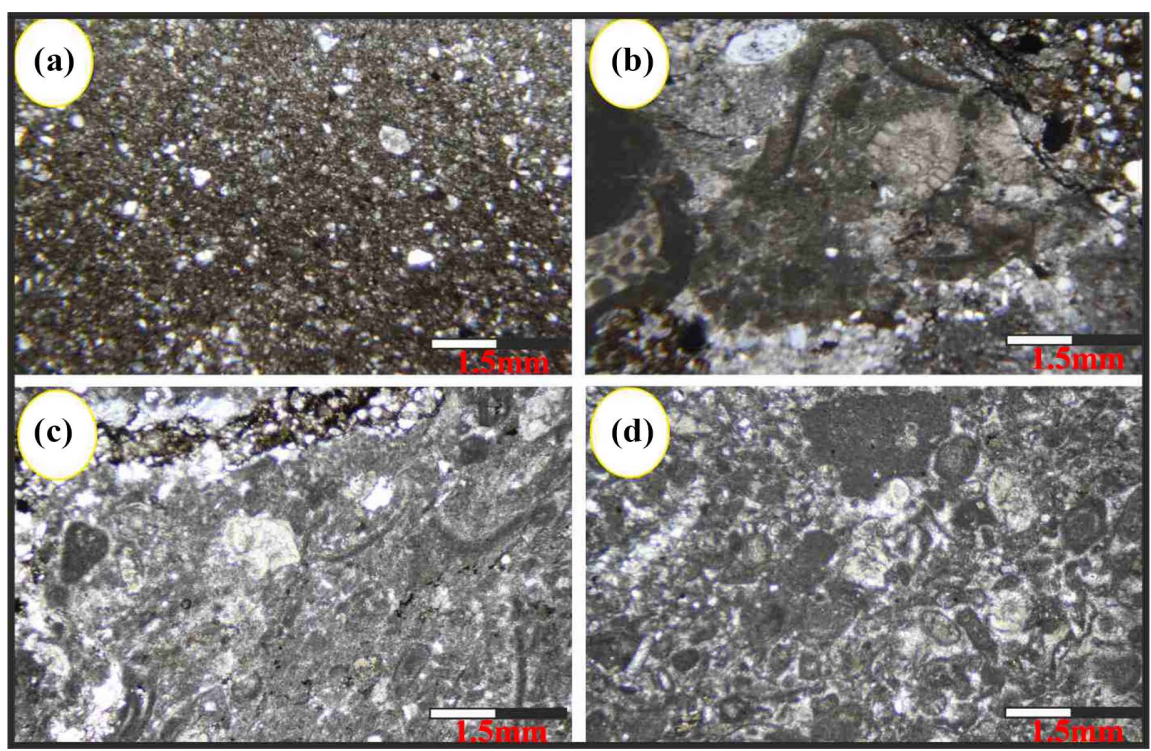

Figure 6. (a), (b) Sandy mudstone microfacies. The quartz grains and bioclasts are visible in the photos (under normal light). (c), (d) Interclast bioclast wackestone/packstone. Bioclasts and interclasts are visible in the photos (PPL). 
during breaking the pre-rounded grains and are located in a carbonate matrix without contact with each others. Textural maturity of the microfacies is immature due to the presence of abundant cement and matrix. The indeterminate microfossils fragments broken and transported and can be seen in calcite cement. The main characteristics of this facies belt are the presence of sand-sized quartz clastic grains, the secondary calcite veins with low variability of fossil assemblages in the tidal flat Mf5 microfacies. The presence of calcite veins and also stylolites in the microfacies is one of the features of intertidal flat and supratidal flat which have displacement with spreading to the land [28]. The detrital loads such as quartz grains in the lime mud matrix represent the tidal flat for this microfacies [29].

\subsection{Interclast Bioclast Wackestone/Packstone (Mf7)}

In the field observations, the microfacies is dark gray color, with medium to thick-bedded layers which interclasts and microfossils can be observed with the naked eyes. The microfacies only are exposed in the end of the middle part of the Abaregh section with medium-bedded limestones. The most allochems of the microfacies are composed of skeletal fragments and bioclasts about 5\%-15\%. The bioclasts are including the bivalve and algae fragments or indeterminate fossils which are allochthonnous and have been transported to the environment (Figure 6). The difference between this microfacies with Mf8 is an increase in the amount of interclast (20\%). The allochems within the microfacies have strongly micritized. Due to the absence or very low diversity of bioclasts and cooperation with the shallow facies, the sub-environments of tidal flat is recommended for the microfacies [30]. The sedimentation changes from clastic to carbonate occur near the coast areas and inter-ramp where the river eroded the detrital particles and transported to the sea. Also, the residue of bioclasts which observed in the Mf7 microfacies is another feature of tidal flat facies belt.

\section{Lagoonal Facies Belts}

The microfacies group is located between tidal flat and reef microfacies. The lagoon microfacies has alternating with shale facies. The facies belt consists of two facies, thin to medium bedded and dark limestone and with alternating tidal flat and barrier facies.

\subsection{Miliolid Peloid Bioclast Wackestone (Mf8)}

The main components of the microfacies are the imperforated larger benthic foraminifera (Miliolids) with high frequency and with a small amount of benthic foraminifera (small Miscellanea). Other bioclasts include green algae, crustose coralline red algae and bivalve fragments are rarely present (Figure 7). The frequency of peloid grains is about $15 \%$ with good roundness and in a micritic matrix. The wackestone matrix with fragmentation of the foraminiferal shells is justifiable in the facies. The presence of skeletal grains with low diversity and the algae is one of the features of lagoonal facies belt. The miliolid, green algae and 


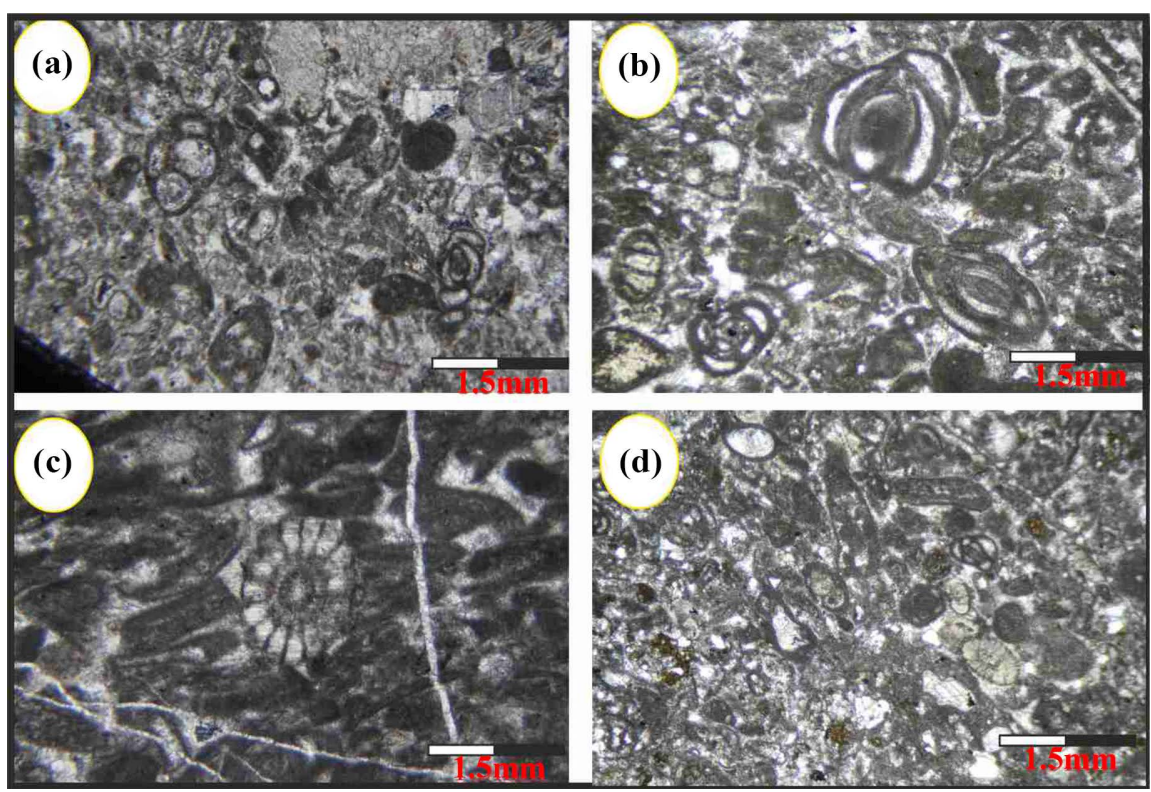

Figure 7. (a), (b) Miliolid peloid bioclast wackestone. The miliolids and peloid grains can be identified in the photos. (c), (d) Algae bioclast packstone/wackestone. The algae, other bioclasts and complete fossils can be observed in the photos (PPL).

small amount of indeterminate fossils in micritic matrix indicate deposition in a lagoon environment with low energy [31]. The peloid in lime mud matrix and low diversity of fossils represent deposition in restricted shallow sub-tidal environment with low sedimentation rate. The imperforate foraminifera such as miliolids with high frequency indicate hypersaline, shallow restricted lagoon [32].

\subsection{Algae Bioclast Packstone/Wackestone (Mf9)}

This microfacies is characterized by abundant crustose coralline red algae (Such as Lithothamnion sp.). Also, the calcareous bioclasts including the fragments of bivalve are rarely present. Also small amounts of detrital quartz are present in this facies (Figure 7). Moreover, the abundant bioclasts (often bivalve fragments) with poor sorting and algae represent an environment with medium energy. Also, the presence of detrital quartz with poor sorting suggests deposition near the source region. According to the studies by Bachman and Hirsch [33] and Penny et al [34], the presence of green algae shows a lagoon environment.

\section{Barrier Facies Belt}

The barrier facies belt has abundant fossils in the studied area and based on 2 microfacies are introduced.

\subsection{Coral Boundstone (Mf10)}

The microfacies with limited lateral extension is in the upper part of the Sekonj section (Figure 8). The main components of the microfacies are only corals (Figure 8). In the field observations, this microfacies is characterized by gray to 

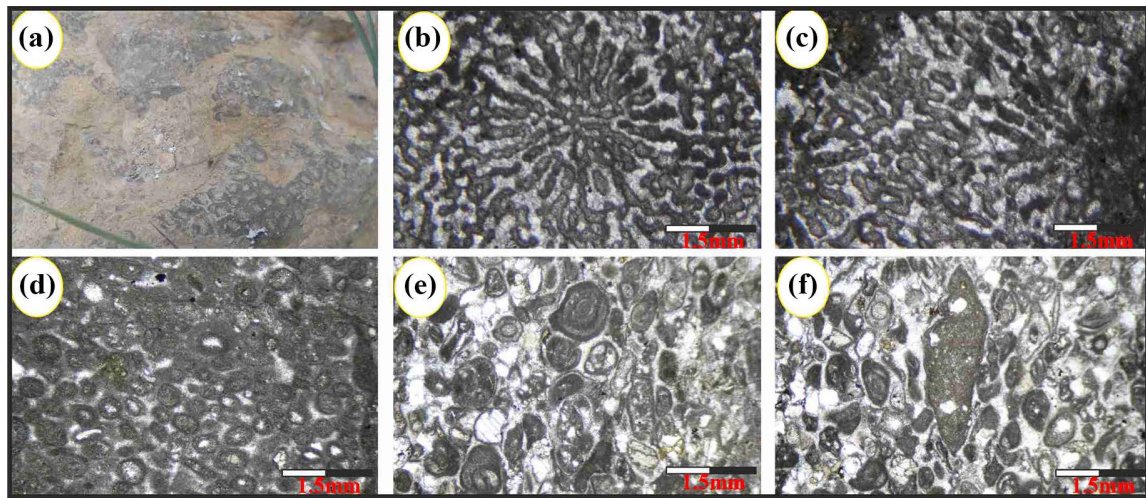

Figure 8. (a) A close-up view of boundstone succession in the field observations. (b), (c). Coral boundstone microfacies (under normal light). (d)-(f) Bioclast peloid ooid packstone/grainstone microfacies. Fossil, peloid and ooid are clearly visible in three images (PPL).

cream-colored, medium-bedded limestone. Also, small amounts of other bioclasts can be seen in the microfacies. The micritic cements have filled most of the porosity and cavities in the corals. The microfacies are association with Mf9 microfacies in the facies column and its limited extension in the field observations represents deposition as patch reefs in the lagoon toward the carbonate barrier and open marine. The boundstone is interpreted to be formed above the fairweather wave base and in a high energy environment which the autochthonous carbonate are formed and based on the occurrence of coral boundstone facies suggests a high energy barrier environment.

\subsection{Bioclast Peloid Ooid Packstone/Grainstone (Mf11)}

This facies is in the middle and upper part of the Abaregh section and in the upper part of the Sekonj section (Figure 8). This microfacies is characterized by gray, thin to thick-bedded limestone with alternating shale facies. Peloid and ooild with more than $25 \%$ are the most abundant non-skeletal particles. In some places of the microfacies, peloids are micritized which indicate energy fluctuations. Minor constituent is composed of less than 5\% bioclast and interclast (Figure 8). Abundance of allochems, presence of ooilds with tangential texture, small amounts of lime mud and abundance of cement in this facies belt show a high energy environment [35]. Also, the presence of peloid and indeterminate ooids suggest a barrier environment and above the fair-weather wave base. The ooids in the Mf11 microfacies represent a shallow, high energy and turbulent environment which suggests deposition in ooidal carbonate barrier.

\section{Open Marine Facies Belt}

In the field observations, this facies belt is medium to thick-bedded and darker than barrier facies belt. All of the proximal open marine microfacies have low thickness than other facies belts in the stratigraphic column. The proximal open marine facies belt is composed of one microfacies which can be seen in the stratigraphic column. 


\section{Bioclast Packstone/Wackstone (Mf13)}

In the field observations, the apparent evidence of this facies is similar the lagoon facies. This facies can be seen in different parts of the succession in the Sekonj section and in the middle part of the Abaregh section. Allochems of this microfacies are including $40 \%$ echinoid fragments and larger benthic foraminifera with 50\% lime mud and the other is cement (Figure 9). This facies with althernating Mf8 microfacies has similar fossil fragments. The similarity between the skeletal fragments of this facies with bioclasts of barrier facies indicates deposition in the upper part of the carbonate barrier and in the proximal open marine. Diversity and the bioclasts size in this microfacies show deposition in the open marine sub-environments [35]. The presence of deep sea benthic foraminifera suggests deposition in shallow open marine environment.

\section{Depositional Paleoenvironment}

The Paleocene-Eocene carbonate-siliciclastic sedimentary successions in the east of Central Iran have significant development, distribution and thickness which as a result of the wide stratigraphic distortion during the tectonic events were not well studied. Laramide event formed the Kerman conglomerate during the late Mesozoic era in most areas of Kerman which represents the marine regression conditions. According to the obtained information from the analysis microfacies, depositional environment and also the absence of storm facies, the $\mathrm{Pa}$ leocene-Eocene succession has been deposited in a carbonate-siliciclastic ramp in the studied area. Spreading of the carbonate barrier dunes facies shows the ramp environment [36]. The possibility of the rimmed-shelf existence requires the presence of barrier reef in the area. However, the barrier environment of the studied area is limited to the patch reefs assemblages which are separated the lagoon from the open marine sub-environments. The gradual changes of facies, presence of barrier and the absence of sliding and slumping facies with the macroscopic and microscopic characteristics of carbonate-siliciclastic facies and comparison with the models presented by [37] and indicate that the facies have been deposited in a shallow marine environment, in a mixed carbonate-siliciclastic ramp. By studying thin sections, determining depositional microfacies and comparing with the current depositional environments, a range from lagoon to open marine environment has been identified which separated by barrier and patch reef. Coastal, tidal flat, lagoon, barrier, patch reefs and proximal open

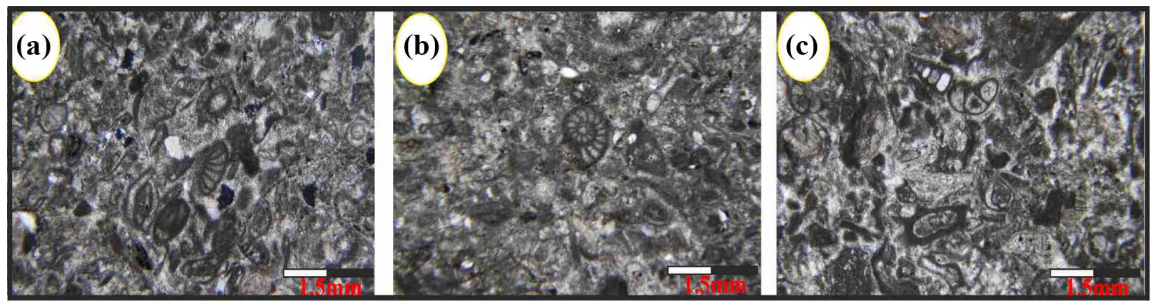

Figure 9. (a)-(c) Bioclast packstone/wackstone with different fossils in the proximal open marine (PPL). 
marine facies belts of the depositional paleoenvironment were formed the carbonate-siliciclastic ramp (Figure 10).

\section{Sequence Stratigraphy}

According to the sequence stratigraphy studies of Paleocene-Eocene succession in the studied area, there are two important points including: 1) sediments have been deposited in coastal and shallow marine basin. 2) the nature of carbonate and siliciclastic were existed in the time of formation in the basin. The studied sections are composed of two 3rd incomplete depositional sequences which include 4 system tracts (Figure 11).

\subsection{Sequence 1}

The sequence 1 with a thickness of 249 and 126 meter are respectively identified in the Sekonj and Abaregh sections which represent a carbonate and a little siliciclastic sequence and has been deposited in coastal, tidal flat, barrier and proximal open marine environments. The sequence has high thickness in the Sekonj section and the thickness of siliciclastic layers gradually increase from the bottom to up of the succession. The sequence 1 with low thickness in the Abaregh section is more siliciclastic and gradually converts into the carbonate facies. In

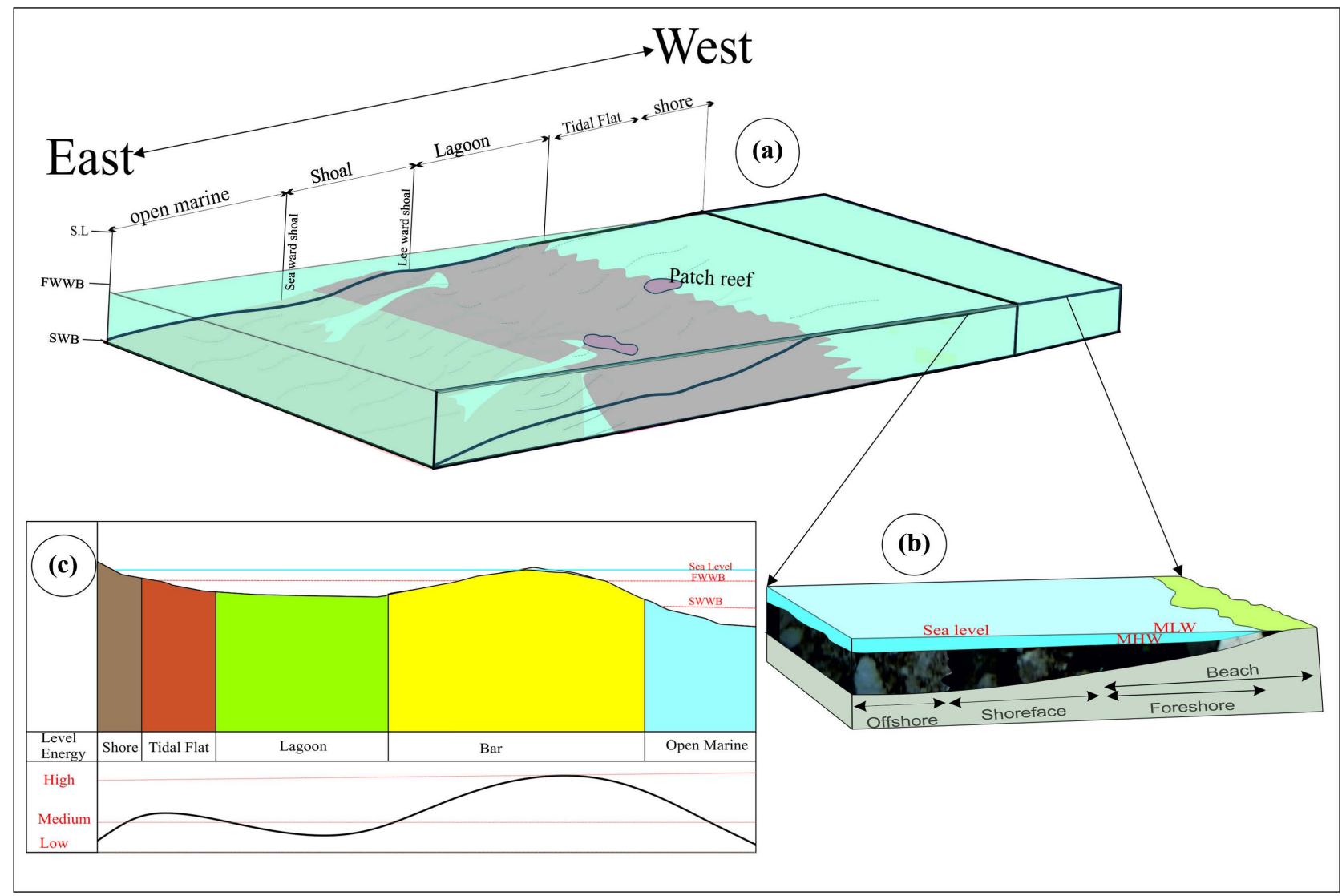

Figure 10. (a) Depositional paleoenvironment model of Paleocene-Eocene succession in the studied area. (b) Subdivision in the coastal environment. (c) Transverse profile of depositional paleoenvironment in the studied area and energy level in the different parts of the studied succession. 


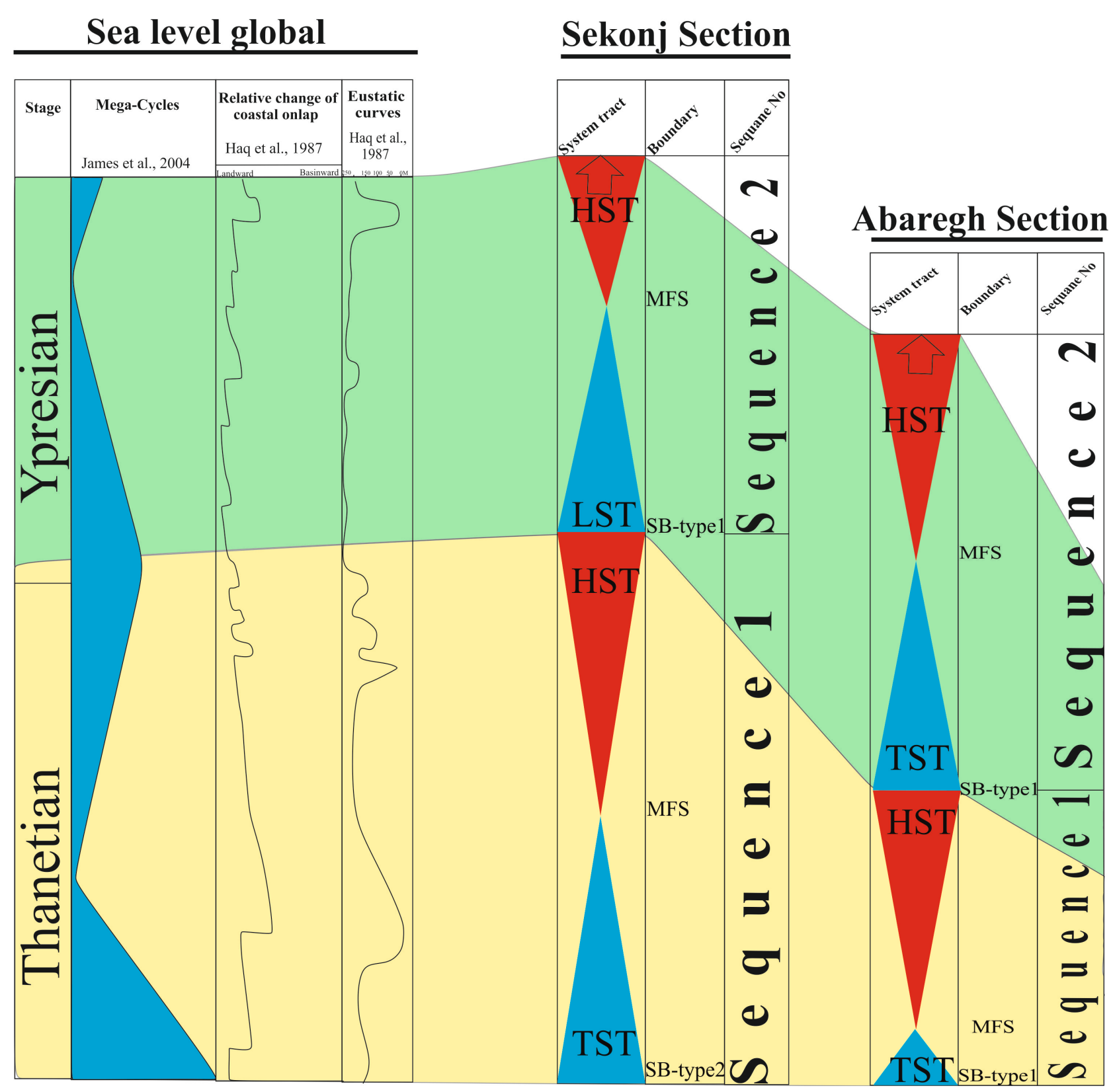

Figure 11. Correlation of sequence stratigraphy in the studied sections with global sea level changes.

addition, the sequence has been deposited during the period of rising sea level and the Paleocene-Eocene carbonate succession is placed on the thick bedded Cretaceous carbonate succession in the Sekonj section. The sediments have been deposited unconformably on the Kerman conglomerate deposits in the Abaregh section. The field and laboratory observations show that the boundary between the Paleocene-Eocene and the Cretaceous carbonate successions is gradual and continuous and there is no evidence of out of the water and regression conditions. Hence, the lower boundary of this sequence is a type 2 (SB2) (Figure 3 and Figure 4). The first depositional sequence has been placed unconformably on the Kerman conglomerate deposits in the Abaregh section. So, the lower boundary of this sequence with Kerman conglomerate is a type 1 (SB1). The 
conversion of Cretaceous thick-bedded limestone to Paleocene-Eocene thin to medium-bedded limestone shows a small amount of water depth reduction. Due to the absence of sufficient evidences, lowstand system tract (LST) is not identifiable from transgressive system tract (TST) in the both sections.

So, the sequence is started with the transgressive system tract (TST) on top of the sequence boundary (Figure 3 and Figure 4). Transgressive system tract (TST) has been deposited in proximal open marine, lagoon and barrier facies belts which indicate the rate of the sedimentation is more than the accommodation space. But, the system tract has been deposited in tidal flat facies belt in the Abaregh section. Highstand systems tract (HST) ended to sequence boundary type 1 (SB1) and is characterized by coastal microfacies and the sandstone with cross-lamination in the Sekonj section and with the conglomerate succession in the Abaregh section. The early highstand systems tract in Sekonj section is characterized by a proliferation of grain-supported shoal facies. This part mainly comprises the shoal and shore facies association. The overhead part of sequence 1 (late HST) indicates upward shallowing trend. The shallowing-upward trend from shore and tidal flat is indicative of a progradational stacking pattern during the highstand systems tract. Maximum flooding surface ( $\mathrm{mfs}$ ) is characterized by lagoon microfacies (Mf9) in the Sekonj section and tidal flat microfacies (Mf7) in the Abaregh section. It seems that the sedimentation phase is calmer and accumulation pattern is in the shallow sediments which represent the accommodation space is less than the rate of the sedimentation. The falling sea level was occurred after maximum flooding surface ( $\mathrm{mfs}$ ) and ended to coastal facies and show a shallowing upward parasequence.

\subsection{Sequence 2}

The sequence 2 is not completely identifiable, since the end of the studied sections has been covered (Figure 11). The sequence 2 with a thickness of 165 and 199 meter are respectively in the Sekonj and Abaregh sections. Sequence 2 is in the Sekonj section with more siliciclastic nature and the interbedded limestone can be seen in some places. But, the sequence is composed of limestone with interbedded sandstone and shale layers in the Abaregh section. Three system tracts have been identified in the Sekonj section, but due to the absence of sufficient evidences, separation of transgressive system tract (TST) from lowstand system tract (LST) was not possible in the both sections. Sequence 2 has lagoonal nature in the Sekonj section and coastal nature in the Abaregh section. Lowstand system tract (LST) is located on the sequence boundary type 1 (SB1) and has a constant trend. The system tract has been just identified in the Sekonj section and includes coral reef boundstone succession. It seems that the system tract was a shallow environment and gradually increased its depth and reached to the shale facies which indicates the maximum flooding surface (mfs). The highstand systems tract (HST) overlying the maximum flooding surface (mfs) shows a regressive trend in the both sections. Also, the rate of sedimentation is more than accommodation space. The end of this system tract is not identifiable due to the 
lack of outcrop and coverage.

\subsection{Correlation of Sequence Stratigraphy in the Studied Sections}

Sequence 1 is mainly composed of limestone in the Sekonj section and alternating limestone, sandstone, shale and conglomerate in the Abaregh section. Sequence 1 has abundant algae fragments in the limestone successions in the both sections. The lower boundary of sequence 1 is a type 2 sequence boundary (SB2) which the mentioned limestone succession overlies the Cretaceous thick-bedded limestone succession in the Sekonj section, while the mentioned limestone succession has been deposited on the Kerman conglomerate in the Abaregh section. This difference indicates that the Kerman conglomerate successions have not been deposited in the Sekonj section or have been removed as a result of the tectonic activities. In addition, the maximum thickness of the sequence 1 is belongs to the Sekonj section, while the conditions are reversed in the sequence 2. The thickness of succession has been reduced from East to the West of the basin. This is so that, at first the limestone succession and then siliciclastic succession have been deposited in the north of basin (Sekonj section) and the thickness of limestone succession is more than siliciclastic succession. Generally, the global sea level changes included two transgressions at the time of deposition of this succession which are match with the transgression and regression of sea water in the sequence 1 and 2 of the studied area (Figure 11). The role of tectonic activities become more upward the basin and high rate of the subsidence in the basin led to increase the accommodation space and sediment supply in both sections. A long period of shoal conditions in Sekonj section and lagoon conditions in Abaregh section, reflecting a balanced situation between accommodation and sedimentation, characterizes the aggradational sedimention pattern.

\section{Conclusion}

Generally, the Palecene-Eocene succession is present in some part of the south of Kerman, due to erosion during the Laramide orogeny event but the basal part of Palecene-Eocene succession of Thanetian-Ypersian age in the sections, transgressively overlies the top of late Cretaceous and Kerman Conglomerate. Quaternary sediments are usually the upper border of the above sequence. PaleceneEocene succession in the Study area basin mainly consists of carbonate-clastic (limestone, dolomite, sandstone, shales, Conglomerate). The other two sections are characterized by a mixed succession of carbonate siliciclastic shelf deposits. The regional differentiation most probably reflects their position on separate tectonic blocks on which different facies conditions developed due to different tectonic movements. Facies, depositional environment and sequence stratigraphy studies of Palecene-Eocene successions in Sekonj sedimentary trough provided the following consequences: Identification of 11 microfacies in 5 facies belts including coastal, tidal flat, lagoon, barrier and proximal open marine environments which have been deposited in a carboanate-siliciclastic ramp. The most observed siliciclastic facies are in the Sekonj section which all of the silicic- 
lastic facies can be seen in it. The observed facies and microfacies are including: Mf1, Mf2, Mf3, Mf4, Mf5, Mf8, Mf9, Mf10, Mf11, Mf13 in the Sekonj section and Mf1, Mf3, Mf4, Mf5, Mf7, Mf8, Mf9, Mf11, Mf13 in the Abaregh section. The lateral trend of facies and microfacies from Sekonj section to Abaregh section is characterized by deposition of carbonate microfacies containing miliolids, algae and fossil fragments in the lower part of the Sekonj section and upper part of the Abaregh section. Sequence stratigraphy analysis of the studied sediments led to identification of two 3rd depositional sequences with 2 maximum flooding surfaces. So, four system tracts were separated from together in the Sekonj section. Sequence 1 has been completely observed in the both sections, but due to the lack of outcrop, the sequence 2 was not completely interpreted at the end of the succession. In addition, the regional tectonic activities caused the differences in the two sequences. The predominant facies associations developed in Palecene-Eocene demonstrate an overall transgression-regression cycle in the study area.

\section{References}

[1] Dimitriovic, M.D. (1973) Geology of Kerman Region. Institute for Geological and Mining Exploration of Iran, Report No. Y/52, 335 p.

[2] Aghanabati, A. (2006) Geology of Iran. Geological Survey \& Mineral Explorations of Iran (GSI), 586 p. (In Persian)

[3] Abbasnejad, A. and Dastanpour, M. (1998) Earthquakes and Seismicity of the Kerman Province. Kerman Cultural Services Publication, 255 p. (In Persian)

[4] Hajian, J. (1996) Geology of Iran, Paleocene-Eocene in Iran. Geological Survey of Iran, 460 p. (In Persian)

[5] Shahmoradi, M. and Faryabi, A. (2011) Biostratigraphy and Paleoecology of the Paleocene-Eocene Deposits Foraminifera in Abaregh Section, NW of Bam, Kerman. 2nd Geological Congress of Iranian Plateau, University of Zarand in Kerman. (In Persian)

[6] Samadi Afkham, M. (2012) Biostratigraphy and Microfacies Studies of the Paleocene-Eocene Depositional Succession in the North of Khoosf (Dahanrud Section), East of Iran. M.S.c Geology' Thesis (The Field of Stratigraphy and Paleontology), University of Birjand, 145 p. (In Persian)

[7] Hashemiazizi, S.H., Miranshabestari, Q.R. and Khazaei, A.R. (2013) Petrography, Depositional Facies and Diagenesis Analysis of Paleocene-Eocene Carbonate Deposits in Ching Anticline in the West of Birjand, East of Iran. The Journal of Sedimentary Facies, 29, 107-122. (In Persian)

[8] Babazadeh, S.A. (2014) Statistical Analysis of Foraminifera in the Eocene Ramp in the Lut Block, East of Iran. Stratigraphic and Sedimentological Journal, 30, 73-88. (In Persian)

[9] Shokuhimoghadam, N., Miranshabestari, Q.R. and Khazaie, A.R. (2011) Microfacies and Depositional Environment of Paleocene-Eocene Carbonate Succession in the South East of Birjand, East of Iran. Journal of Sedimentary Facies, 4, 172-187. (In Persian)

[10] MoeinAldini, Z., Faryabi, A., Raeis Alsadat, S.N. and Lotf Abad Arab, A. (2013) Analysis the Biogenic Structures of the Paleocene Eocene Flysch Deposits in Chahartagari Section, SE of Kerman. Journal of Paleontology, 1, 103-113. (In Persian) 
[11] Gitashenasi Cartographic and Geographical Institute (2007) Road Atlas of Iran, Scale of $1 / 100000$.

[12] Sahandi, M. R. and Rahim-zadeh, F. (1992) Geological Map of Kerman 1/250000. Geological Survey \& Mineral Explorations of Iran (GSI).

[13] Djokovic, I., Dimitrijevic, M.N., Cvetic, S. and Dimitrijevic, M.D. (1978) Geological Map of Khaneh Khatun 1/100000. Geological Survey \& Mineral Explorations of Iran (GSI).

[14] Azizan, H.A., Shahraki, A. and Safoori, S. (1999) Geological Map of Kerman 1/100000. Geological Survey \& Mineral Explorations of Iran (GSI).

[15] Walker, R. and Jackson, J. (2004) Active Tectonics and Late Cenozoic Strain Distribution in Central and Eastern Iran. Tectonics, 23, TC5010. https://doi.org/10.1029/2003TC001529

[16] Shafiebafti, A., Pour Kermani, M., Shahpasand-Zadeh, M. and Iran Manesh, F. (2008) Tectonic Geomorphology and Analysis of the Kuh-Banan Fault Activity by Calculating Geomorphic Indices. Journal of Geology and Environment, No. 7, 1-17. (In Persian)

[17] Flugel, E. (2010) Microfacies of Carbonate Rocks, Analysis, Interpretation and Application. Springer-Verlag, Berlin, $976 \mathrm{p}$.

[18] Pettijohn, F.J. (1975) Sedimentary Rocks. Harper and Row, New York, 628 p.

[19] Dunham, R.G. (1962) Classification of Carbonate Rocks According to Depositional Texture. In: Ham, W.E., Ed., Classification of Carbonate Rocks, American Association of Petroleum, Geologists Memoir 1, 108-121.

[20] Catuneanu, O. (2006) Principles of Sequence Stratigraphy. Department of Earth and Atopospheric Science, University of Alberta Edmonton, Alberta, Canada, 387 p.

[21] Catuneanu, O., Abreu, V., Bhattacharya, J., Blum, M., Dalrymple, R., Eriksson, P., Fielding, C.R., Fisher, W., Galloway, W., Gibling, M., Giles, K.A., Holbrook, J.M., Jordanm, R., Kendall, C.G.St.C., Macurda, B., Martinsen, O.J., Miall, A.D., Neal, J.E., Nummedal, D., Pomar, L., Posamentier, H.W., Pratt, B.R., Sarg, J.F. Shanley, K.W., Steel, R.J., Strasser, A., Tucker, M.E. and Winker, C. (2009) Towards the Standardization of Sequence Stratigraphy. Earth-Science Reviews, 92, 1-33.

[22] Catuneanu, O., Galloway, W.E., Kendall, C.G.S.C., Miall, A.D., Posamentier, H.W., Strasser, A. and Tucker, M.A. (2011) Sequence Stratigraphy: Methodology and Nomenclature. Newsletters on Stratigraphy, 44, 173-245. https://doi.org/10.1127/0078-0421/2011/0011

[23] Tucker, M.E. (2001) Sedimentary Petrology: An Introduction to the Origin of Sedimentary Rocks. Blackwell, Hoboken, 262 p.

[24] Miall, A.D. (2000) Principle of Sedimentary Basin Analysis. Springer-Verlag, New York, 668 p. https://doi.org/10.1007/978-3-662-03999-1

[25] Wanas, H.A. and Abdel-Maguid, N.M. (2006) Petrography and Geochemistry of the Cambro-Ordovician Wajid Sandstone, Southwest Saudi Arabia: Implications for Provenance and Tectonic Setting. Journal of Asian Earth Sciences, 27, 416-429.

[26] Pettijohn, F.J., Potter, P.E. and Siever, R. (1987) Sand and Sandstone. 2nd Edition, Springer, New York, 553 p. https://doi.org/10.1007/978-1-4612-1066-5

[27] Kostic, B., Bech, A. and Aigner, T. (2005) 3-D Sedimentary Architecture of a Quaternary Gravel Delta (SW-Germany): Implication for Hydrostratigraphy. Sedimentary Geology, 181, 147-171.

[28] Shinn, E.A. (1983) Tidal Flat Environment. AAPG Mem, 33, 173-210.

[29] Palma, R.M., Lopez-Gomez, J. and Piethe, R.D. (2007) Oxfordian Ramp System (La 
Manga Formation) in the Bardas Blancas Area (Mendoza Province) Neuquén Basin, Argentina: Facies and Depositional Sequences. Sedimentary Geology, 195, 113-134.

[30] Jamalian, M., Adabi, M.H., Moussavi, M.R., Sadeghi, A., Baghbani, D. and Ariyafar, B. (2011) Facies Characteristic and Paleoenvironmental Reconstruction of the Fahliyan Formation, Lower Cretaceous, in the Kuh-e Siah area, Zagros Basin, Southern Iran. Facies, 57, 101-122.

[31] Geel, T. (2000) Recognition of Stratigraphic Sequence in Carbonate Platform and Slope Deposits: Empirical Models Based on Microfacies Analysis of Palaeogene Deposits in South Eastern Spain. Palaeogeography, Palaeoclimatology, Palaeoecology, 155, 211-238.

[32] Wilson, J.L. (1975) Carbonate Facies in Geologic History. Springer Verlag, New York, 471p. https://doi.org/10.1007/978-1-4612-6383-8

[33] Bachmann, M. and Hirsch, F. (2006) Lower Cretaceous Carbonate Platform of the Eastern LEVANT (Galilee and the Golan Heights): Stratigraphy and Second-Order Sea-Level Change. Cretaceous Research, 27, 487-512.

[34] Penney, S.J. and Racey, A. (2004) Ecology of Extant Nummulitids and Other Larger Benthic Foraminifera: Applications in Palaeoenvironmental Analysis. Earth-Science Reviews, 67, 219-265.

[35] Spalletti, L.A., Poire, D.G.E. and Schwartz, G.V.D. (2001) Sedimentologic of a Neocomian Marine Carbonate-Siliciclastic Ramp: Neuquen Basin Argentina. South America. Journal of Earth Sciences, 14, 609-624.

[36] Elrick, M. and Read, J.F. (1991) Cyclic Ramp to Basin Carbonate Deposits, Lower Mississippian, Wyoming and Montana. Journal of Sedimentary Petrology, 61, 11941224.

[37] Selly, R.C. (1996) Anicient Sedimentary Environments and Their Sub-Surface Diagnosis. 4th Edition, Nelson Thornes (Publisher) Ltd., England, 315 p.

\section{Submit or recommend next manuscript to SCIRP and we will provide best} service for you:

Accepting pre-submission inquiries through Email, Facebook, LinkedIn, Twitter, etc. A wide selection of journals (inclusive of 9 subjects, more than 200 journals)

Providing 24-hour high-quality service

User-friendly online submission system

Fair and swift peer-review system

Efficient typesetting and proofreading procedure

Display of the result of downloads and visits, as well as the number of cited articles

Maximum dissemination of your research work

Submit your manuscript at: http://papersubmission.scirp.org/

Or contact ojg@scirp.org 